\title{
Dynamics of chemical changes through production of various composts/vermicompost such as farm manure and sugar industry wastes
}

\author{
Rahmat Ullah Shah • Muhammad Abid • \\ Muhammad Farooq Qayyum • Rehmat Ullah
}

Received: 22 July 2014/ Accepted: 3 February 2015 / Published online: 17 February 2015

(C) The Author(s) 2015. This article is published with open access at Springerlink.com

\begin{abstract}
Purpose Owing to aridity in our agro-ecosystem, mineralization of organic substrate is quite rapid and thereafter volatilized due to lower matrix affinity. In these consequences, the study has been chalked out with the hypothesis to alter the best approaches for mineralization of available organic resources as soil supplement to reduce the economic burden on the farming community. Our laboratory study showed the sequential temporal variations in physic-chemical properties of available organic substrates such as farm manure and sugar industry waste during composting/vermicomposting.

Methods The organic material obtained from the farm manure of live-stock farm and another sources of industrial organic waste \{sugarcane baggase (SCB), pressmud (SPM), mixture of SCB, SPM and sugarcane effluent $\}$ were used for this mineralization perspectives. However, all organic substrates properties remained static except moisture up to a period of 21 days. Thereafter, these produced and processed matrix was subsequently composted and vermicomposted during 45 days under normal shade. No earthworms were spiked in composting while Lumbricus rubellus collected near vicinity of research area were inoculated at the rate of $50 \mathrm{~g} / \mathrm{kg}$ of waste in vermicomposting. Contrarily, their applications was mandated as and when required policy subsequently. Moisture and temperature status of substrates were monitored regularly.
\end{abstract}

R. U. Shah $(\varangle) \cdot$ M. Abid · M. F. Qayyum

Department of Soil Science, Faculty of agricultural sciences and Technology, Bahaud din Zakariya University, Multan, Pakistan e-mail: rahmatshah78@yahoo.com

R. Ullah

Soil and Water Testing Laboratory, Rajanpur, Punjab, Pakistan
However, compost/vermicompost substrates were assessed @ 15 days interval to evaluate temporal changes in physico-chemical characteristics.

Results Vermicomposting of farm manure and sugar industry wastes produced best quality manure with enriched nutritional status comprising more OC (4\%), N (3\%), $\mathrm{P}$ $(2 \%), \mathrm{K}(7 \%), \mathrm{Ca}(3.5 \%), \mathrm{Na}(2.5 \%), \mathrm{SO}_{4}^{-2}(3.1 \%)$ and $\mathrm{B}$ (twofold) as compared to composting.

Conclusion Inoculation of local specie for vermicomposting is a viable option to be recommended to the farming community.

Keywords Composting $\cdot$ Vermicomposting $\cdot$ Raw organic sources - Local earth worms - Chemical change

\section{Background}

The earth being a natural planet is practically involved in the service of mankind through many attributes (Rockström et al. 2009). It has been playing pivotal role for the sustainability of this universe (Schellnhuber 2004). In this study, major role has been exploited by the mankind need. This could be emphasized by only providing the humanity as food, feed and shelter. The global population is increasing and because of this, the world may experience great fresh water scarcity. Our water resources are limited and, hence, water treatment and recycling methods are the only alternatives for getting fresh water in the forthcoming decades. Therefore, there is a great need for the development of a suitable, inexpensive and rapid wastewater treatment techniques and reuse or conservation methods in the present century. The different types of water treatment and recycling techniques have been discussed in terms of their basic principles, applications, costs, maintenance and 
suitability. Additionally, a systematic approach to water treatment and recycling involving their understanding, evaluation and selection parameters has identified for best humanity interest (Gupta et al. 2012a, b). Among all subcontinents, our country has been mainly known as agricultural country throughout the world (Anderson et al. 2010). Our economy central linchpin is directly linked with sustainability of production from the agricultural scope of system (Zaman et al. 2012). Pakistan is basically comprised of total area of $79.61 \mathrm{M}$ ha, cultivated area of $22.51 \mathrm{M}$ ha, uncultivated area of $23.25 \mathrm{M}$ ha and fallow lands of $7.05 \mathrm{M}$ ha (Anonymous 2011). Our country has been mainly dependent on DoFasla crop system (Ullah et al. 2012).

About 500 tons of industrial wastes (liquid and solid) being discharged daily from sugar factory during crushing season and presently dumped in vicinity of the sugar factory in our country. The quantity of wastes, however, depends on the crushing capacity of sugar mills (Arainet al. 2004). More than 12 million tons of sugarcane press mud (Sardar et al. 2012) and sugarcane baggase is being produced annually by running 80 sugar mills all over the country. Different types of organic wastes are available, but still cost effective technology has not yet been established to use them effectively. Yet, quality of such produced irrigation water could be improved through addition of carbon based material like compost for the elimination of pollutants. In this regard, various strategies such as the activated carbon reactor and advanced oxidation process (Gupta et al. 2012a, b), implication of matrix such as coloring techniques, Congo red and triarylmethane dye Light Green SF (Mittal et al. 2009a, b, 2010a, b), formation and classification of alumina-coated carbon nano-tubes (Gupta et al. 2011), retrieval of Chrysoidine Y (Mittal et al. 2010a, b), novel organic waste mixture with $\mathrm{Fe}_{2} \mathrm{O}_{3}$ nanoparticles (Gupta and Nayak 2012), photo-remediation of multi walled organic adsorbent (Saleh and Gupta 2012a, b), multi-walled carbon nanotubes-ionic liquid-carbon paste electrode (Khani et al. 2010), C-source material (Karthikeyan et al. 2012) and various organic sources (Jain et al. 2003) for the removal of lethal pollutants from agriculture waste water.

Moreover, compost is available at farmer's field level, cheap and best available source of substrate for compost and vermicompost production (Said et al. 2010). Average amount of nutrients depleted from soil for 100 MT sugarcane production are $\mathrm{N}, \mathrm{P}, \mathrm{K}, \mathrm{Ca}, \mathrm{Mg}, \mathrm{S}, \mathrm{Fe}, \mathrm{Mn}, \mathrm{Zn}$ and $\mathrm{Cu}$ i.e. $148.00,123.00,238.00,42.00,39.00,38.00,7.50,4.12$, 0.50 , and $0.10 \mathrm{~kg}$, respectively (Calcino 1995). Major part of these crop nutrients' is being removed from agricultural soil and discharge and dumped in the vicinity of mills in the form of sugarcane industrial wastes. These industrial wastes have sufficient amount of macro and micronutrients
(Subba 2012). All these nutrients can be effectively recycled for the improvement of soil fertility index and crop yield (Hussein and Anjum 1999).

Most of literature has overlooked the importance of composting and vermicomposting technology in existing cropping schemes. However, many scientists revealed that the use of composting and vermicomposting approaches might be encouraged on large scale spectrum. Now, it is a dire need of today of our developing country that inclusion of micro-organism based technology should be mandated and suggested to our farming community strongly by our policy makers. Keeping in view of these facts, our planned study has been initiated with the objectives to evaluate the production and characterization of compost and vermicompost through their changes in our existing environmental conditions of Punjab-Pakistan. The produce and outcome of compost and vermicompost organic substrate would be efficiently used for maintaining the soil fertility as a supplementary source of fertilization in our country.

\section{Methods}

Hajra Rehman Sugar Mills, district Muzaffer Garh, PunjabPakistan was selected for the collection of available organic substrates. However, these waste organic resources have been used for the composting and vermicomposting procedure in the Research area of Bahaud din Zakariya University, Multan. Therefore, two hundred kilogram of sugarcane baggase (SCB), sugarcane press-mud (SCPM) and $50 \mathrm{~L}$ effluents from sugarcane industry (SCE) was collected in plastic bags and cans, respectively. These materials were labeled, packed in their respective material; then brought to laboratory and stored in main godown (store) of the research area of Soil Science Department. In addition to this, the livestock farm situated near the university main gate was visited. The material was physically checked properly through feel method. Then, this material was packed in $50 \mathrm{~kg}$ plastic bags and labeled properly with permanent marker on both sides of each bag. Only two bags were loaded and brought to laboratory and stored in the main godown (store) of research area of Soil Science Department.

Next day, the 54 (fifty-four) soil pits having dimension of $2 \times 2 \times 2$ feet $(\mathrm{L} \times \mathrm{W} \times \mathrm{D})$ were developed using shovel under the green shade area of our Research Farm. Besides this, the stored materials of sugar cane industry and dairy farm waste were air dried on polythene sheet under the normal shade. The base of each soil pit was leveled with its original soil. Each side of soil pits with plastic sheets was covered. Each of the six soil pits was filled with $15 \mathrm{~kg}$ of sugar cane baggase, pressmud, sugarcane baggase + pressmud + effluent $(1: 1: 1)$ and farm manure. 
These soil pits were covered by plastic sheets under the shade for 21 days. The moisture content was initially determined from each soil pits to maintain it up to $60 \%$ by thermohygrometer. It would be maintained through water sprinkling up to desired moisture content level.

The covering of plastic sheet having raw material low density polyethylene (LDPE) and ethylene-vinylacetate (EVA) containing 80-170 $\mu \mathrm{m}$ thickness of each soil pits have raised the internal temperature that leads towards the sanitation of substrate matrix. Each soil pits remained covered up till 21 days. Then after this period, the upper covered plastic sheets were removed and these soil pits permanently remained opened under the shade. After 21 days, available local earthworm species (Lumbricus rubellus) from the banks of unpaved water channel and moist/green leaf debris, present near research area of Bahaud din Zakariya University Multan with acclimatized soil/material were collected in well aerated, open plastic buckets and brought to experimental site. Each vermicomposting soil pits was spiked with $50 \mathrm{~g}$ of local specie of earth worms and did not inoculated in all composting soil pits. It is important to note that thin layer of acclimatized material of local earth worm species were spread on substrate of each soil pits of vermicomposting. Temporal changes were stipulated by this meter by applying moisture to maintain its temperature up to 25 to $35^{\circ} \mathrm{C}$ and moisture contents up to already mentioned desired level.

The samples of each organic substrate were collected at $0,15,30$ and 45 days after inoculation of local earth worms. All the substrate samples were collected in plastic ribbon bags, marked with permanent marker and brought to laboratory for analyses of chemical changes. Under controlled environmental conditions, following parameters were determined as per established methodologies for characterization of compost and vermicompost.

The moisture content (\%) of all collected organic samples was determined by gravimetric method (Hess and Angelaki 2003). The $\mathrm{pH}$ of the filtrate of each organic substarte was estimated by $\mathrm{pH}$ meter (Alves et al. 2006). Total nitrogen (ppm) was estimated by Kjeldahldistillation method (Bremner 1996). The organic carbon content (ppm) was recorded by chromic acid oxidation and titrimetric method (Walky and Black 1934). Prior to this, calcium contents (ppm) of all organic substrate samples after digestion process were estimated by versenate titration method (Hess and Angelaki 2003). Phosphorous, potassium, sodium, sulpher, boron contents (ppm) of each sample was determined by standard method of Jackson, using flame photometer (Rashid 1986). At the end, the concentrations of boron (ppm) were determined through HCL boiling procedure by using colorimetric method (Bingham 1982).

\section{Results}

Moisture retention capacity (\%)

For moisture retention capacity, usage of various raw organic substrates through processes of composting and vermicomposting has been tabulated in Table 1. It was found that raw organic source from sugarcane baggase has hold moisture contents sequentially and significantly $(P<0.01)$ throughout the process of both composting practices (Table 1). However, it was observed that it retained less (48.29 and $48.33 \%$ ) during 45 days after inoculation of earth worms (DAI) in both practices. Raw organic source of pressmud also hold significantly $(P<0.01)$ moisture profile initially increased and then decreased sequentially throughout the entire process of both practices. Similarly, this source has retained more moisture content (48.41 and $48.69 \%$ ) especially at 45 DAI in both composting mechanisms. Prior to this, mixture of Sugarcane \{baggase, pressmud and effluent $\}$ has also maintained moisture status significantly $(P<0.01)$ throughout the both experimentation. Likewise, their mixture has subsequently sustained more moisture profile (61.28 and $61.12 \%)$ at 0 DAI during all process of composting. Besides this, raw organic source from farm manure has retained less moisture contents significantly $(P<0.01)$ with heterogenic trend in both practices. Less moisture retention (46.12 and $47.19 \%$ ) was noted markedly at 45 DAI during composting and vermicomposting. Subsequently, it was noticed generally that moisture contents increased initially at 0 DAI and then decreased sequentially at 15,30 and 45 DAI in all treatments of raw organic sources during composting and vermicomposting strategies. However, our values expressed moisture behavior in this sense that net retention capacity was found significantly $(P<0.01)$ in sugarcane baggase, pressmud, mixture of sugarcane \{baggase, pressmud and effluent $\}$ and farm manure under both processes. Therefore, it was noted that less net retention capacity of various available organic raw sources was observed for moisture contents in farm manure $(-2.62 \%)$ as compared to sugarcane baggase $(-2.41 \%)$, pressmud $(-1.51 \%)$ and their mixture $(-1.19 \%)$ respectively, under composting practice only. Therefore, less net retention capacity of various available organic raw sources was observed for moisture contents in farm manure $(-3.19 \%)$ as compared to pressmud $(-2.48 \%)$, sugarcane baggase $(-2.32 \%)$, and their mixture $(-2.16 \%)$ respectively, under vermicomposting practice. However, it was observed that less net retention capacity of all raw organic material for moisture contents was noticed at 45 DAI under both processes. Hence, farm manure has retained less net moisture retention capacity than to all other organic sources, respectively, under both practices. 


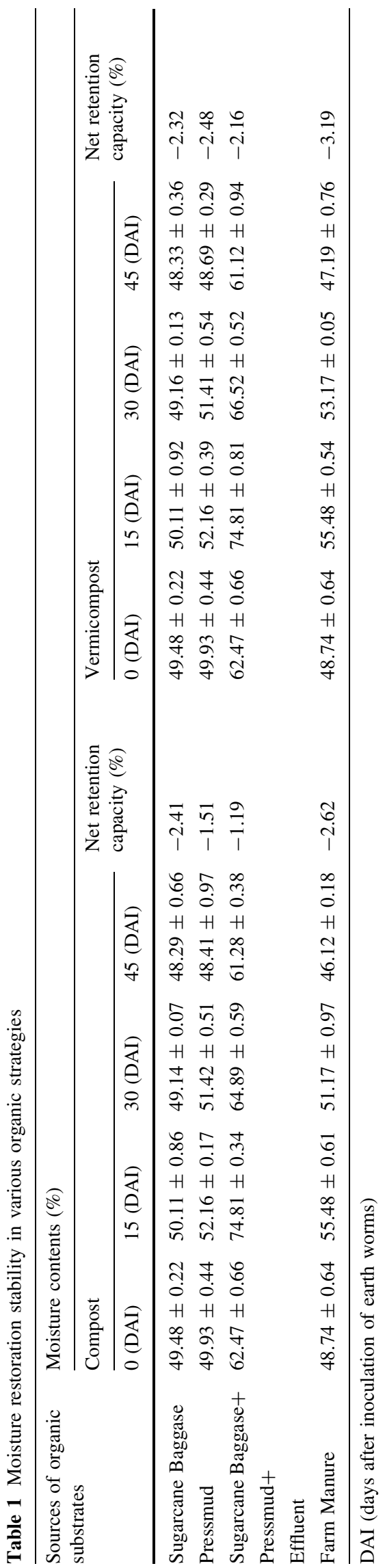

$\mathrm{pH}$ trend

The $\mathrm{pH}$ of composting and vermicomposting materials tend to decrease with incubation time in all organic waste materials tested (Table 2). In this context, our results annotated that it varied significantly during 45 days after inoculation of earth worms (DAI) in both practices. Raw organic source of pressmud also changed significantly $(P<0.01) \mathrm{pH}$ trend throughout the entire process of both practices. Similarly, this source has also changed $\mathrm{pH}$ status especially at 45 DAI in both composting mechanisms. Besides this, mixture of sugarcane \{baggase, pressmud and effluent \}as also lowered down the $\mathrm{pH}$ status significantly $(P<0.01)$ throughout the both experimentation. Analogously, their mixture has subsequently piled up more acidic $\mathrm{pH}$ status at 45 DAI during all process of composting. Moreover, raw organic source from farm manure has also shown gradient increment of $\mathrm{pH}$ level significantly $(P<0.01)$ with passage of time up to end of both practices. Lowest $\mathrm{pH}$ value was observed in farm manure compost and vermicmpost from pressmud. Subsequently, it was noticed generally that $\mathrm{pH}$ trend did not increase initially at 0 DAI and then decreased sequentially at 15,30 and 45 DAI in all treatments of raw organic sources during composting and vermicomposting strategies. $\mathrm{pH}$ reaction varied in this way that net variation rate was observed significantly $(P<0.01)$ in sugarcane baggase, pressmud, mixture of sugarcane \{baggase, pressmud and effluent $\}$ and farm manure under both processes. Therefore, it was observed that minimum net variation rate of various available organic raw sources was observed for $\mathrm{pH}$ status in farm manure $(-10.39$ and $-12.98 \%)$ as compared to their mixture $(-6.57$ and $-5.26 \%)$, Pressmud $(-4.0$ and $-5.33 \%)$ and sugarcane baggase $(-5.19 \%)$ respectively, under composting and vermicomposting practice only. It was observed that more net variation rate of all raw organic material for $\mathrm{pH}$ trend was noticed at 45 DAI under composting and vermicomposting processes. However, farm manure yielded less net variation rate amid other organic amendments under composting and vermicomposting technologies.

Nutrients dynamics in compost and vermicompost material

The data in Tables 3, 4, 5, 6, 7, 8, 9, 10 regarding to nutrient related element such as $\mathrm{OC}, \mathrm{N}, \mathrm{P}, \mathrm{K}, \mathrm{Ca}, \mathrm{Na}^{+}, \mathrm{S}$ and $\mathrm{B}$ depicted that raw organic source from sugarcane baggase, sugarcane pressmud, sugarcane effluent and farm manure mineralized sequentially and significantly $(P<0.01)$ throughout the process of mineralization under 
Table $2 \mathrm{pH}$ trends of various organic strategies

\begin{tabular}{|c|c|c|c|c|c|c|c|c|c|c|}
\hline \multirow{3}{*}{$\begin{array}{l}\text { Sources of } \\
\text { organic } \\
\text { substrates }\end{array}$} & \multicolumn{10}{|l|}{ (pH trends) } \\
\hline & \multicolumn{4}{|l|}{ Compost } & \multirow{2}{*}{$\begin{array}{l}\text { Net } \\
\text { retention } \\
\text { capacity } \\
(\%)\end{array}$} & \multicolumn{4}{|c|}{ Vermicompost } & \multirow{2}{*}{$\begin{array}{l}\text { Net } \\
\text { retention } \\
\text { capacity } \\
(\%)\end{array}$} \\
\hline & 0 (DAI) & 15 (DAI) & 30 (DAI) & 45 (DAI) & & 0 (DAI) & 15 (DAI) & 30 (DAI) & 45 (DAI) & \\
\hline $\begin{array}{c}\text { Sugarcane } \\
\text { Baggase }\end{array}$ & $7.7 \pm 0.10$ & $7.6 \pm 0.08$ & $7.5 \pm 0.09$ & $7.3 \pm 0.10$ & -5.19 & $7.7 \pm 0.10$ & $7.6 \pm 0.08$ & $7.4 \pm 0.08$ & $7.3 \pm 0.10$ & -5.19 \\
\hline Pressmud & $7.5 \pm 0.09$ & $7.5 \pm 0.10$ & $7.4 \pm 0.10$ & $7.2 \pm 0.09$ & -4 & $7.5 \pm 0.09$ & $7.4 \pm 0.10$ & $7.2 \pm 0.10$ & $7.1 \pm 0.09$ & -5.33 \\
\hline $\begin{array}{l}\text { Sugarcane } \\
\text { Baggase+ }\end{array}$ & $7.6 \pm 0.08$ & $7.5 \pm 0.09$ & $7.3 \pm 0.08$ & $7.2 \pm 0.08$ & -6.57 & $7.6 \pm 0.08$ & $7.5 \pm 0.10$ & $7.4 \pm 0.08$ & $7.1 \pm 0.08$ & -5.26 \\
\hline \multicolumn{11}{|l|}{ Pressmud+ } \\
\hline \multicolumn{11}{|l|}{ Effluent } \\
\hline $\begin{array}{l}\text { Farm } \\
\text { Manure }\end{array}$ & $7.7 \pm 0.09$ & $7.5 \pm 0.09$ & $7.2 \pm 0.09$ & $7.1 \pm 0.09$ & -10.39 & $7.7 \pm 0.09$ & $7.6 \pm 0.09$ & $7.1 \pm 0.09$ & $7.1 \pm 0.09$ & -12.98 \\
\hline
\end{tabular}

DAI (days after inoculation of earth worms)

both composting practices. Therefore it is revealed from our data that, OC remained up to 17.41 and $18.34 \mathrm{~g} \mathrm{~kg}^{-1}$, $\mathrm{N}$ remained up to 1.33 and $1.34 \mathrm{~g} \mathrm{~kg}^{-1}$, $\mathrm{P}$ remained up to 0.69 and $0.77 \mathrm{~g} \mathrm{~kg}^{-1}$, $\mathrm{K}$ remained up to 1.93 and $1.96 \mathrm{~g} \mathrm{~kg}^{-1}$, Ca remained up to 1.85 and $1.89 \mathrm{~g} \mathrm{~kg}^{-1}$, Na remained up to 0.48 and $0.49 \%, \mathrm{~S}$ remained up to 1.39 and $1.41 \mathrm{mg} \mathrm{kg}^{-1}$ and $\mathrm{B}$ remained up to 13.46 and $15.82 \mathrm{~g} \mathrm{~kg}^{-1}$ during 45 days after inoculation of earth worms (DAI) in both practices. Likewise, raw organic source of pressmud also produced significantly $(P<0.01)$ median contents of $\mathrm{OC}$ remained up to 17.41 and $18.34 \mathrm{~g} \mathrm{~kg}^{-1}, \mathrm{~N}$ remained up to 1.58 and $1.60 \mathrm{~g} \mathrm{~kg}^{-1}, \mathrm{P}$ remained up to 2.73 and $2.79 \mathrm{~g} \mathrm{~kg}^{-1}$, $\mathrm{K}$ remained up to 2.24 and $2.27 \mathrm{~g} \mathrm{~kg}^{-1}, \mathrm{Ca}$ remained up to 2.61 and $2.71 \mathrm{~g} \mathrm{~kg}^{-1}$, Na remained up to 0.56 and $0.58 \%$, S remained up to 2.12 and $2.23 \mathrm{mg} \mathrm{kg}^{-1}$ and $\mathrm{B}$ remained up to 16.16 and $17.62 \mathrm{~g} \mathrm{~kg}^{-1}$ throughout the entire process of both practices. Moreover, mixture of sugarcane \{baggase, pressmud and effluent $\}$ has also enhanced the status of OC which remained (17.41 and $18.34 \mathrm{~g} \mathrm{~kg}^{-1}$ ), $\mathrm{N}$ remained up to $\left(1.42\right.$ and $\left.1.44 \mathrm{~g} \mathrm{~kg}^{-1}\right), \mathrm{P}$ remained up to $(2.01$ and $\left.2.07 \mathrm{~g} \mathrm{~kg}^{-1}\right), \mathrm{K}$ remained up to (3.67 and $\left.4.27 \mathrm{~g} \mathrm{~kg}^{-1}\right), \mathrm{Ca}$ remained up to (4.68 and $4.79 \mathrm{~g} \mathrm{~kg}^{-1}$ ), Na remained up to (1.57 and $1.62 \%), \mathrm{S}$ remained up to (2.31 and $\left.2.37 \mathrm{mg} \mathrm{kg}^{-1}\right)$ and $\mathrm{B}$ remained up to (12.34 and $\left.15.34 \mathrm{~g} \mathrm{~kg}^{-1}\right)$ significantly $(P<0.01)$ throughout both experimentation. Besides this, raw organic source from farm manure has also shown gradient increment of OC which remained (17.41 and $\left.18.34 \mathrm{~g} \mathrm{~kg}^{-1}\right), \mathrm{N}$ remained up to $\left(2.31\right.$ and $\left.2.34 \mathrm{~g} \mathrm{~kg}^{-1}\right), \mathrm{P}$ remained up to (5.32 and $\left.5.61 \mathrm{~g} \mathrm{~kg}^{-1}\right), \mathrm{K}$ remained up to ( 4.99 and $\left.5.86 \mathrm{~g} \mathrm{~kg}^{-1}\right), \mathrm{Ca}$ remained up to $\left(6.88\right.$ and $\left.6.97 \mathrm{~g} \mathrm{~kg}^{-1}\right)$, Na remained up to $(1.18$ and $1.21 \%), \mathrm{S}$ remained up to $(2.10$ and $\left.2.13 \mathrm{mg} \mathrm{kg}^{-1}\right)$ and $\mathrm{B}$ remained up to $(17.10$ and $\left.20.10 \mathrm{~g} \mathrm{~kg}^{-1}\right)$ strength significantly $(P<0.01)$ with passage of time remained up to the end of both practices.

More contents of OC, N, P, K, Ca, Na, S and B were noted markedly at 45 DAI during composting and vermicomposting. Factually, it was noticed generally that contents of all nutrients did not increase initially at 0 DAI and then increased sequentially at 15, 30 and 45 DAI in all treatments of raw organic sources during composting and vermicomposting strategies. However, our values depicted picture in this way that net mineralization rate was found significantly $(P<0.01)$ in sugarcane baggase, pressmud, mixture of sugarcane $\{$ baggase, pressmud and effluent $\}$ and farm manure under both processes.

For OC, maximum net mineralization rate of various available organic raw sources was observed in farm manure (29.64 and $32.54 \%$ ) as compared to their mixture (14.72 and $19.61 \%$ ), Pressmud (36.28 and $39.83 \%$ ) and sugarcane baggase (12.83 and $18.59 \%$ ) respectively, under both composting practices. Likewise, maximum net mineralization rate of $\mathrm{N}$ was noted in farm manure (7.94 and $9.34 \%)$ as compared to Pressmud (3.26 and $4.57 \%$ ), sugarcane baggase (3.1 and $3.87 \%)$ and mixture of sugarcane baggase, pressmud and effluent ( 2.16 and $3.59 \%$ ) respectively, under both composting practices. Analogously, maximum net mineralization rate of total phosphorous was markedly observed in farm manure (10.83 and $16.88 \%)$ as compared to sugarcane baggase (6.25 and $7.81 \%$ ), pressmud (4.60 and $6.90 \%)$ and their mixture (2.03 and $5.08 \%)$ respectively, under both composting practices. Equidistantly, maximum net mineralization rate of potassium was found in farm manure (13.44 and $19.35 \%)$ than to the sugarcane mixture (11.58 and $18.01 \%)$, pressmud (9.74 and $16.41 \%$ ) and sugarcane baggase $(4.89$ and $6.52 \%)$ respectively, under both 


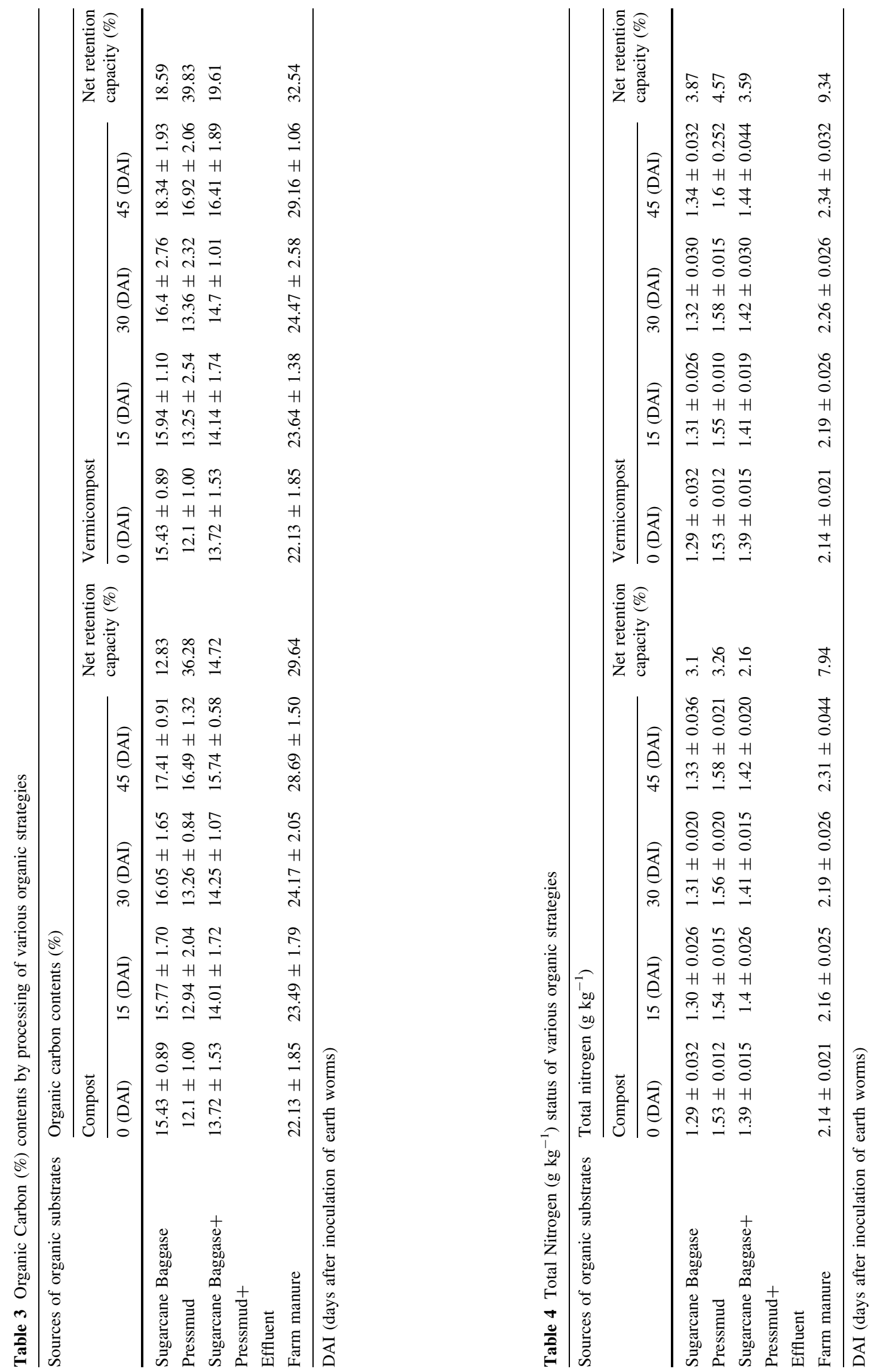



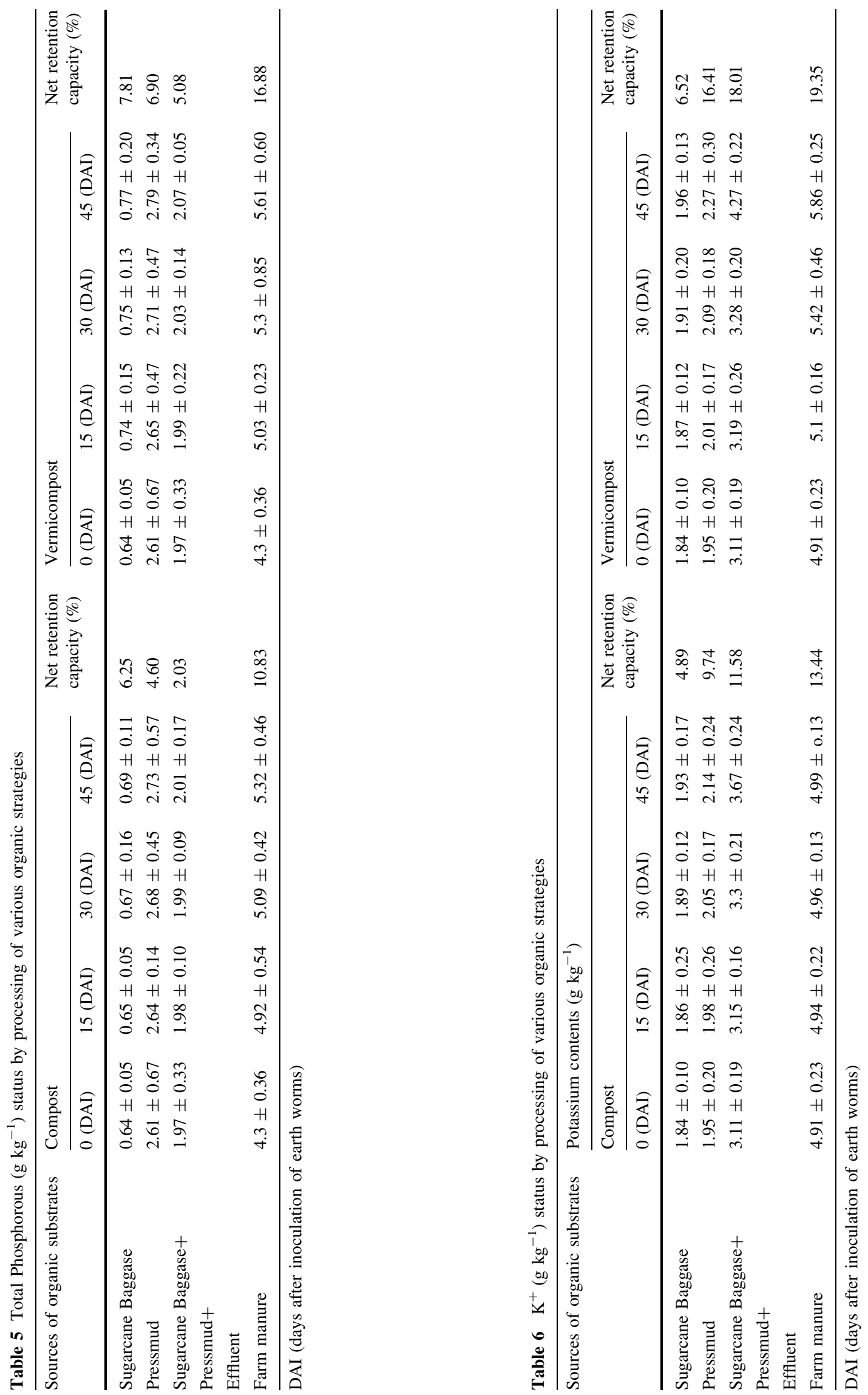

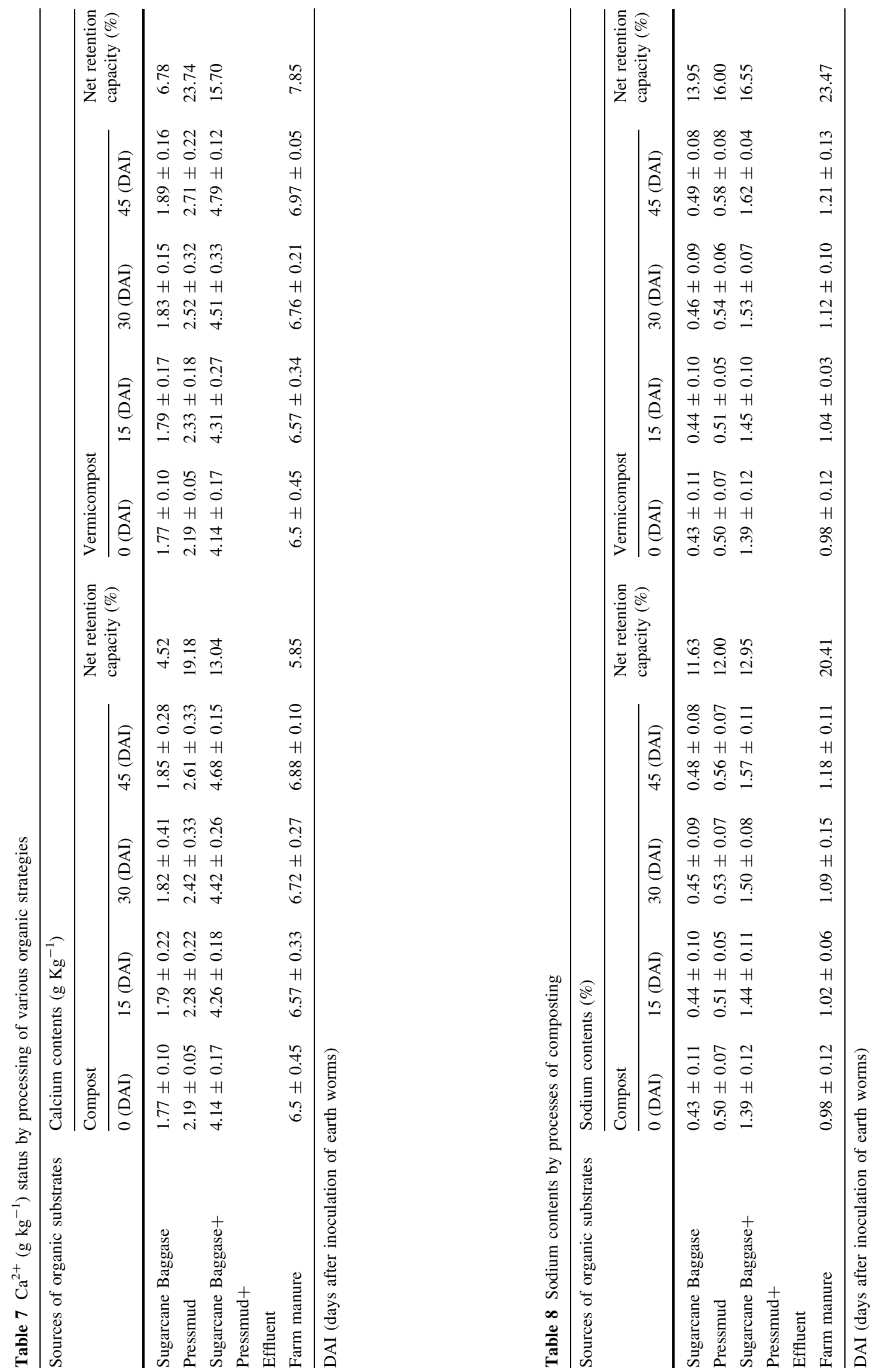


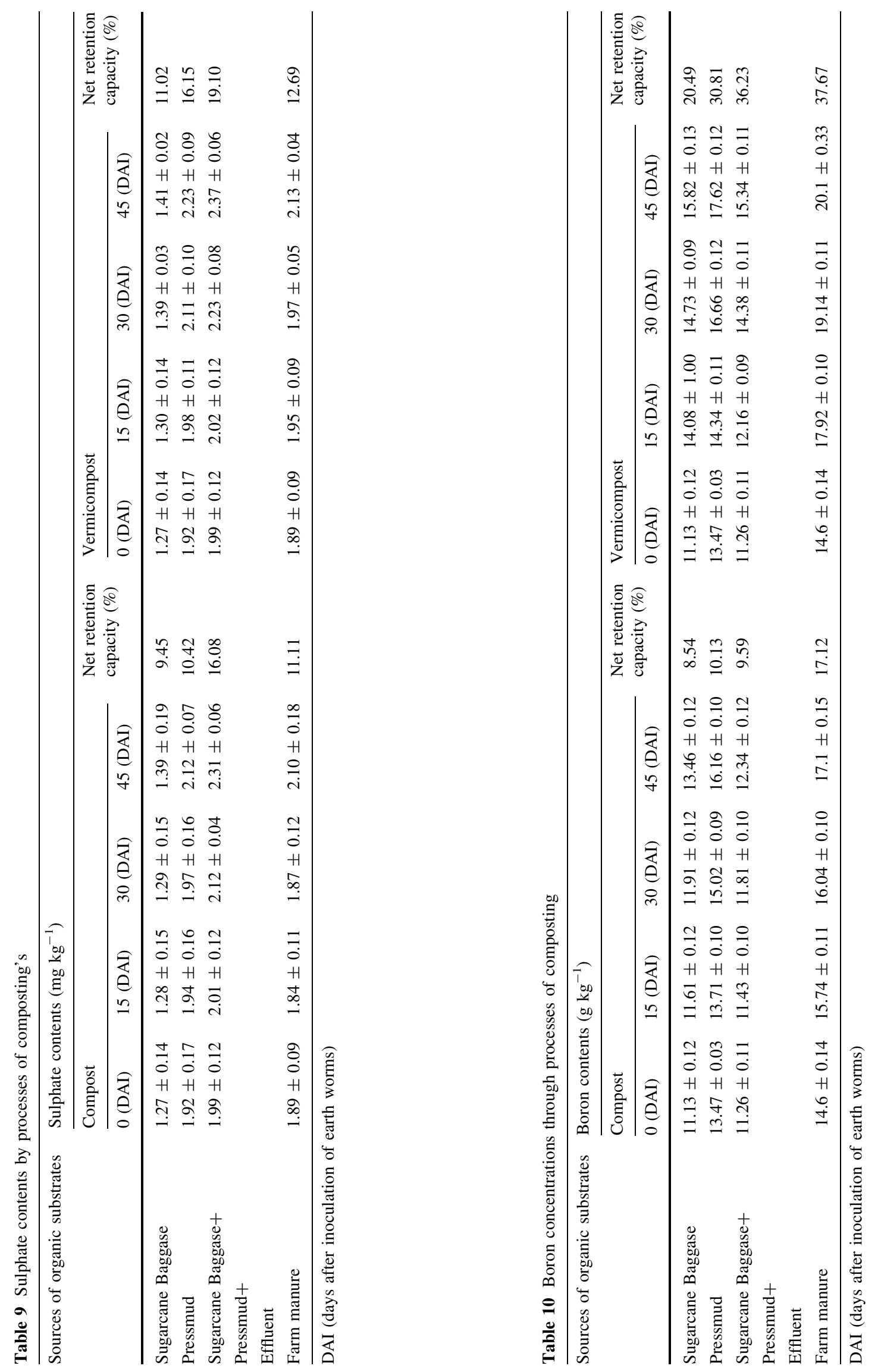


composting practices. For $\mathrm{Ca}$ contents, maximum net mineralization rate was noted in pressmud (19.18 and $23.74 \%)$ as compared to their mixture (13.04 and $15.70 \%$ ), farm manure (5.85 and $7.85 \%$ ) and sugarcane baggase (4.52 and $6.78 \%$ ) respectively, under both composting practices. Prior to this, maximum net mineralization rate of $\mathrm{Na}$ was present in farm manure (20.41 and $23.47 \%$ ) than to the mixture of sugarcane \{baggase, pressmud and effluent $\}$ (12.95 and $16.55 \%$ ), pressmud (12.0 and $16.0 \%$ ) and sugarcane baggase (11.63 and $13.95 \%$ ) respectively, under both composting practices. In addition to this, maximum net mineralization rate of $\mathrm{S}$ was annotated in mixture of sugarcane baggase, pressmud and effluent $\}(16.08 \%)$ than tofarm manure $(11.11 \%)$, pressmud $(10.42 \%)$ and sugarcane baggase $(9.45 \%)$ respectively, under composting process only. Therefore, net mineralization rate under vermicomposting process for sulphate strength was present more in mixture of sugarcane \{baggase, pressmud and effluent\}(19.10\%), pressmud $(16.15 \%)$, farm manure $(12.69 \%)$ and sugarcane baggase $(11.02 \%)$ respectively. For B contents, maximum net mineralization rate was expressed with its median contents infarm manure (17.12 and $37.67 \%$ ) as compared to pressmud (10.13 and $30.81 \%$ ), their mixture (9.59 and $36.23 \%$ ) and sugarcane baggase (8.54 and $20.49 \%$ ) respectively, under both composting process. It was suggested that more net mineralization rate of all raw organic material for nutrient dynamics was noticed at 45 DAI under composting and vermicomposting processes. Hence, it was pointed out finally that farm manure has given maximum nutrient dynamics in both composting processes as compared to all other treatments and suggesting its large scale implication in the field to provide the optimum balance nutrition for the maintenance of crop productivity in their existing cropping patterns.

\section{Discussion}

Vermicomposting being a friendly environment technology had been induced as a precursor for the sustainability of soil mineral liberation to the rhizosphere of many exotic species of Lycopersicum esculentum L. (Reséndez et al. 2012). However, composting in this consortium also made a significant linchpin redox pertaining to sustaining the soil productivity in relation to yield of many crop plants (Hemmat et al. 2010). Prior to this, adoption of these technologies had been evidenced from the recent advancement of the scientific pool of work. Such hallmark had been consolidated on the maintenance of soil fertility indices (Ullah et al. 2013). Our data in above table in this consequence has also depicted soil fertility improved significantly through the implementation of vermicomposting strategies. In this regard, Theunissen et al. (2010) have also primarily focused on the improvement of soil fertility due to inclusion of vermicomposting dilemma. Moreover, many scientific investigations have given clear picture that encoring vermicomposting approach in the arid to hyper arid environmental conditions which proved best tool for the soil fertility improvement (Bhosale et al. 2012). Our investigation favors in this context that vermicomposting valuably improved the soil nitrogen to potassium build up in the soil profile.

Initially, the soil water contents, aeration, availability of organic matter, soil temporal fluctuation and soil mesic properties have been actively involved in the mineralization of available organic source through the efficient microbial activity (Tejada et al. 2009). Our data in Tables 1 and 2 clearly reflected pertaining to availability of optimum soil water content for the active existence of soil niche. Synergistically, it was evident from the suggestion endorsed by Ullah et al. (2013) that active participation of microbial population has vitally mineralized the available organic substrate in the optimum soil water contents.

Soil reaction $(\mathrm{pH})$ has also been annotated as a nerve impulse for the availability of liberated nutrients on the available soil solumn (Lauber et al. 2009). It has to play a precursor for the recommendation of amendment for the amelioration of all nature of virgin to true soils. However, our results advocated the invariability of soil reaction to efflux liberated nutrition from soil matrix. The mica based dominant parent material has naturally acquired the soil reaction in alkaline form. This fact is directly linked with the process of mineralization to yield the soil nutrition perceptiveness (Brady and Weil 2010). Our results expressed in Table 2 are in similar fashion.

Soil nitrogen has been noted markedly from the mineralization process of available organic matter substrate to the existing soil microbial habitat (Raviv et al. 2004). Nitrogen being structural and morphological constituent nutrient has been easily available in vermicomposting to composting technologies as compared to other approaches involved for the organic resources. In this regard, our results in Table 4 clearly support the feasibility of available nitrogen contents for the growth and development of the tomato crop (Fernandez et al. 2010). Another structural strengthening element such as calcium in Table 7 dominating mineral has also pointed out significant release of this element from the soil matrix by activating the redox potential through intrusion of soil biota (Mansfeldt 2004). Its oozing from the soil matrix would have reduced the solubility of lethal element like sodium which in turn hampers the growth and development mechanisms involved in tomato with stand fields. Our suggestions have enabled us from the data (Table 8) that minimum sodium contents might have negative impact on the recovery efficiency for the respiration of microbial 
activity as compared to other nature of organic processes. Such evidence has been amazingly validated by (Wong et al. 2008) that microbial activity remained un-effective on lower salinity stress.

Micronutrients have also been supplementary used for the maintenance of growth process of all nature of crop. Its availability from any medium has been involved for the many physiological mechanisms like photosynthesis, fertilization, xylem solute transportation, cell divisions, stomata functionalities, fruit setting, enzyme activation, carbohydrate mobility, transpiration pull, cell turgidity and immunity against disease infections (Marschner 2012). Our data in this consequence, especially, for the availability of boron and sulphate contents depicted their status (Tables 9 and 10) from the mineralized produce through active participation of earth worms.

Regulation of metabolites in the cell venation to webbing of leaf area would be entangled by the insertion of potassium contents. However, the production of potassium contents through involvement of earth worms and by many other ways might be significantly involved in the aforementioned functions. Moreover, it has primarily participated in the regulation of stomata opening and closing through balancing the $\mathrm{Na}^{+}: \mathrm{K}^{+}$ratio (Ren et al. 2005). Our findings pertaining to potassium contents in Table 6 reflected that optimum potassium median contents have been recovered efficiently through vermicomposting amid to all other strategies for the process of mineralization of organic substrates. Many approaches have also suggested the same suggestions like to our results (Fornes et al. 2012).

Phosphorous plays a pivotal role for root establishment, energy currency, fruit quality, fruit setting, stem strengthens and early maturity of various crops. Its availability is directly linked with the existence of optimum $\mathrm{pH}$. The phosphorous median content has been proliferated sufficiently from the produce of earth worm heaps as compared to all other strategies opted for the decomposition of available raw material in our study. However, this point has been raised by Jouquet et al. (2010) pertaining to availability of phosphorous contents by the implementation of many living to non-living approaches on available organic source pool. Therefore, Rigane et al. (2011) suggestions also coincide to our observation in Table 5 for the availability of phosphorous contents.

Organic matter contents has been processed by vermicomposting and/or by composting from the organic flora raw material, fauna including partially decomposed dead living entities like earthworm and micro to macrobial niche (Jack et al. 2011). This mineralization mechanism of organic matter produces partially to fully decompose organic carbon contents. The organic carbon improves the soil structure, friability, water holding capacity, porosity, tillage, soil fertility which in turn contributes in boosting up the yield of all crops. Our study suggested the suitable quantum of mineralized organic carbon contents through the implementation of vermicomposting technologies when compared with nonvermicomposting technologies (Table 3 ). This paradox has been significantly verified by the recommendations of research advancement. Many researchers (Prakash et al. 2010; Ngo et al. 2011; Subramanian et al. 2010) have also recommended that vermicomposting technology yielded huge pile of organic carbon contents.

\section{Conclusion}

The study conducted on composting and vermicomposting of sugarcane baggase, pressmud, their mixture along with effluent and farm manure suggested many suited approaches. It was noted that composting strategy of sugarcane base raw organic material and farm manure have produced good quality of nutrient enriched material. The vermicomposting also produced huge piles of material but its quality remained best as compared to composting methodologies. Hence, it has been concluded from the study that use of available local earth worm species should be encouraged by incorporating farm manure initially in the field to improve the soil nutrition capability by activating their mineralization activities to reduce the economic burden on the farming community as a policy preview.

Acknowledgments Authors would like to acknowledge from the core of their hearts to Higher Education Commission Islamabad, for providing financial assistance for the completion of this study. I would also thank all the staff of soil and water testing laboratory and Multan for providing technical assistance for the completion of this manuscript.

Conflict of interest The authors declared that they have no conflict of interest.

Open Access This article is distributed under the terms of the Creative Commons Attribution License which permits any use, distribution, and reproduction in any medium, provided the original author(s) and the source are credited.

\section{References}

Alves J, Lombardi M, Lada C (2006) The mass function of dense molecular cores and the origin of the IMF. arXiv preprint astroph/0612126

Anderson K, Cockburn J, Martin W (2010) Agricultural price distortions, inequality and poverty. World Bank Publications, 1818 H street NW Washington DC, pp 209-246

Anonymous (1999) Agriculture Monthly Economic Letter. NBP 26(8):3-4

Anonymous (2011) Pakistan statistical year book 2011 by Federal Bureau of Statistics, Government of Pakistan

Arain MA, Fatima Q (2004) Recycling of sugarcane industrial waste as a biofertilizer through composting. Pak J SciInd R 47(1):34-41 
Bastiaanssen WG, Ali S (2003) A new crop yield forecasting model based on satellite measurements applied across the Indus Basin, Pakistan. Agr Ecosyst Environ 94(3):321-340

Berry T (2013) The sacred universe: Earth, spirituality, and religion in the twenty-first century. Columbia University Press

Bhosale PR, Chonde GS, Nakade DB, Raut PD (2012) Studies on physico-chemical characteristics of waxed and dewaxed pressmud and its effect on water holding capacity of soil. J Biosci 1(1):35-41

Bingham FT (1982) Boron. In: Page AL (ed) Methods of soil analyses, part 2: Chemical and mineralogical properties. Am Soc Agron Madison, WI, pp 431-448

Brady NC, Weil RR (2010) Elements of the nature and properties of soils. Pearson Prentice Hall

Bremner JM, Sparks DL, Page AL, Helmke PA, Loeppert RH, Soltanpour PN, Sumner ME (1996) Nitrogen-total. In: Methods of soil analysis. Part 3-chemical methods. pp 1085-1121

Calcino DV (1995) Australian sugarcane nutrition manual. Published by sugarcane research and development corporation (SRDC). Catena 77:238-247

Conant RT, Ryan MG, Ågren GI, Birge HE, Davidson EA, Eliasson PE, Bradford MA (2011) Temperature and soil organic matter decomposition rates-synthesis of current knowledge and a way forward. Glob Change Biol 17(11):3392-3404

Fernández-Gómez MJ, Nogales R, Insam H, Romero E, Goberna M (2010) Continuous-feeding vermicomposting as a recycling management method to revalue tomato-fruit wastes from greenhouse crops. Waste Manag 30(12):2461-2468

Fornes F, Mendoza-Hernández D, García-de-la-Fuente R, Abad M, Belda RM (2012) Composting versus vermicomposting: a comparative study of organic matter evolution through straight and combined processes. Biores Technol 118:296-305

Gupta VK, Nayak A (2012) Cadmium removal and recovery from aqueous solutions by novel adsorbents prepared from orange peel and $\mathrm{Fe}_{2} \mathrm{O}_{3}$ nanoparticles. Ch Eng J 180:81-90

Gupta VK, Agarwal S, Saleh TA (2011) Synthesis and characterization of alumina-coated carbon nanotubes and their application for lead removal. J Hazard Mat 185(1):17-23

Gupta VK, Ali I, Saleh TA, Nayak A, Agarwal S (2012a) Chemical treatment technologies for waste-water recycling-an overview. RSC Adv 2(16):6380-6388

Gupta VK, Jain R, Mittal A, Tawfik Saleh A, Nayak A, Agarwal S, Sikarwar S (2012b) Photo- catalytic degradation of toxic dye amaranth on $\mathrm{TiO}_{2} / \mathrm{UV}$ in aqueous suspensions. Mat Sci Eng 32(1):12-17

Hemmat A, Aghilinategh N, Rezainejad Y, Sadeghi M (2010) Longterm impacts of municipal solid waste compost, sewage sludge andfarmyard manure application on organic carbon, bulk density and consistencylimits of a calcareous soil in central Iran. Soil Till Res 108(1):43-50

Hess BJ, Angelaki DE (2003) Gravity modulates Listing's plane orientation during both pursuit and saccades. J Neurophysiol 90(2):1340-1345

Hussain T, Anjum S (1999) Role of Biofertilizer in Boosting Agriculture. "Daily Dawn" Economic and Business Review, 4-10 Oct, P.No.3

Jack AL, Rangarajan A, Culman SW, Sooksa-Nguan T, Thies JE (2011) Choice of organic amendments in tomato transplants has lasting effects on bacterial rhizosphere communities and crop performance in the field. Appl Soil Ecol 48(1):94-101

Jackson ML (1967) Soil, chemical analysis. Prentice Hall of India Private Limited, New Delhi

Jain R, Gupta VK, Nayak A, Agarwal S, Shrivastava M (2011) Removal of the hazardous dye- Tartrazine by photodegradation on titanium dioxide surface. Mat Sci Eng 31(5):1062-1067
Jain AK, Gupta VK, Bhatnagar A, Suhas (2003) A comparative study of adsorbents prepared from industrial wastes for removal of dyes. Sep Sci Technol 38(2): 463-481

Jouquet P, Plumere T, Thu TD, Rumpel C, Duc TT, Orange D (2010) The rehabilitation of tropical soils using compost and vermicompost is affected by the presence of endogeic earthworms. Appl Soil Ecol 46(1):125-133

Karthikeyan S, Gupta VK, Boopathy R, Titus A, Sekaran G (2012) A new approach for the degradation of high concentration of aromatic amine by heterocatalytic Fenton oxidation: kinetic and spectroscopic studies. J Mol Liq 173:153-163

Khani H, Rofouei MK, Arab P, Gupta VK, Vafaei Z (2010) Multiwalled carbon nanotubes-ionic liquid-carbon paste electrode as a super selectivity sensor: Application to potentiometric monitoring of mercury ion (II). J Hazard Mat 183(1-3):402-409

Lauber CL, Hamady M, Knight R, Fiere N (2009) Pyrosequencingbased assessment of soil $\mathrm{pH}$ as a predictor of soil bacterial community structure at the continental scale. Appl Environ Biol 75(15):5111-5120

Mansfeldt T (2004) Redox potential of bulk soil and soil solution concentration of nitrate, manganese, iron, and sulfate in two gleysols. J Plant Nutr Soil Sc 167(1):7-16

Marschner H (ed) (2012) Marschner's mineral nutrition of higher plants, vol 89. Academic press, Marschner

Mittal A, Kaur D, Malviya A, Mittal J, Gupta VK (2009a) Adsorption studies on the removal of coloring agent phenol red from wastewater using waste materials as adsorbents. J Colloid Interface Sci 337(2):345-354

Mittal A, Mittal J, Malviya A, Gupta VK (2009b) Adsorptive removal of hazardous anionic dye "Congo red" from wastewater using waste materials and recovery by desorption. J Colloid Interface Sci 340(1):16-26

Mittal A, Mittal J, Malviya A, Gupta VK (2010a) Removal and recovery of Chrysoidine $\mathrm{Y}$ from aqueous solutions by waste materials. J Colloid Interface Sci 344(2):497-507

Mittal A, Mittal J, Malviya A, Kaur D, Gupta VK (2010b) Decoloration treatment of a hazardous triarylmethane dye, Light Green SF (Yellowish) by waste material adsorbents. J Colloid Interface Sci 342(2):518-527

Ngo PT, Rumpel C, Dignac MF, Billou D, Duc TT, Jouquet P (2011) Transformation of buffalo manure by composting or vermicomposting to rehabilitate degraded tropical soils. Ecol Eng 37(2):269-276

Prakash M, Karmegam N (2010) Vermistabilization of pressmud using Perionyx ceylanensis Mich. Biores Technol 101(21): 8464-8468

Rashid A (1986) Mapping zinc fertility of soils using indicator plants and soil analyses. PhD Dissertation, University of Hawaii, HI

Raviv M, Medina S, Krasnovsky A, Ziadna H (2004) Organic matter and nitrogen conservation in manure compost for organic agriculture. Compost Sci Util 12(1):6-10

Ren ZH, Gao JP, Li LG, Cai XL, Huang W, Chao DY, Lin HX (2005) A rice quantitative trait locus for salt tolerance encodes a sodium transporter. Nature Genet 37(10):1141-1146

Reséndez AM, Aguilar FJL, Viramontes UF, Dimas NR, Arroyo JV, Carrillo JLR, Ríos PC, Valdés MHR (2012) Tomato production in sand: vermicompost mixtures compared with sand and nutritive solution. Basic Res J Agri Sc Rev 1(1):19-26

Rigane MK, Medhioub K (2011) Assessment of properties of Tunisian agricultural waste composts: application as components in reconstituted anthropic soils and their effects on tomato yield and quality. Resour Conserv Recy 55(8):785-792

Rockström J, Will S, Kevin N, Åsa P, Chapin FS, Eric FL, Timothy ML, Foley JA (2009) A safe operating space for humanity. Nature 461(7263):472-475 
Said G, Khan MJ, Usman K, Rehman H (2010) Impact of press mud as organic amendment on physico-chemical characteristics of calcareous soil. Sarhad J Agric 26(4):565-570

Saleh TA, Gupta VK (2012a) Photo-catalyzed degradation of hazardous dye methyl orange by use of a composite catalyst consisting of multi-walled carbon nanotubes and titanium dioxide. J Colloid Interface Sci 371(1):101-106

Saleh TA, Gupta VK (2012b) Column with CNT/magnesium oxide composite for lead (II) removal from water. Env Sci Pollut Res 19(4):1224-1228

Sardar S, Ilyas SU, Malik SR, Javaid K (2012) Compost fertilizer production from sugar press mud (SPM). Int $\mathrm{J}$ Chem Environ Eng 3(1):39-43

Schellnhuber HJ (ed) (2004) Earth system analysis for sustainability. MIT Press

Srivastava SK, Gupta VK, Mohan D, Sharma S (1997) Design parameters for fixed bed reactors of activated carbon developed from fertilizer waste for the removal of some heavy metal ions. Waste Manag 17(8):517-522

Subba RB (2012) Sugar factory and allied industrial wastes. Basic Res J Agri Sci Rev. 1(1):19-26

Subramanian S, Sivarajan M, Saravanapriya S (2010) Chemical changes during vermicomposting of sago industry solid wastes. J Hazard Mat 179(1):318-322

Tejada M, García-Martínez AM, Parrado J (2009) Effects of a vermicompost composted with beet vinasse on soil properties, soil losses and soil restoration. Catena 77(3):238-247

Theunissen J, Ndakidemi PA, Laubscher CP (2010) Review: potential of vermicompost produced from plant wasteon the growth and nutrient status in vegetable-production. Int $\mathrm{J}$ Phy Sci 5(13): 1964-1973

Ullah R, Lone MI, Mian SM, Ali S, Ullah KS, Sheikh AA, Ali I (2012) Impact of seasonal variations and cropping systems on soil microbial biomass and enzymatic activities in slope gradient moisture stressed soils of Punjab-Pakistan. Soil Environ 31(1):21-29

Ullah R, Lone MI, Khan KSK, Mehdi SM, Qazi MA (2013) Effect of cropping systems and seasonal variations on soil microbial biomass and enzymatic activities in arid soils. J Ani Plant Sci 23(2):493-499

Walkley A, Black CA (1934) Anexamination of the Degtjaraff method for determining soil organic matter and a proposed modification of the chromic acid titration method. Soil Sci 37:29-38

Wong VN, Dalal RC, Greene RS (2008) Salinity and sodicity effects on respiration and microbial biomass of soil. Biol Fert Soils 44(7):943-953

Zaman K, Khan MM, Ahmad M, Rustam R (2012) The relationship between agricultural technology and energy demand in Pakistan. Energ Policy 44:268-279

Rahmat Ullah Shah is a PhD Indigenous Scholar under the financial assistance of wining Higher Education Scholarship from HECPakistan and working as a PhD student at the Department of Soil Science, Faculty of agricultural sciences and Technology, Bahaud din Zakariya University, Multan-Pakistan. 